\title{
Experimental Based Teaching Approach and Architectural Students Performance
}

Mona M. Abdelhamid

Architectural Engineering Department, Pharos University in Alexandria, Canal ElMahmoudia Street, P.O.

Box 37, Sidi Gaber, 21311 Alexandria, Egypt

\begin{abstract}
:
Architectural studies is one of the hardest carrier, students face different challenges during their journey up to graduation project. These challenges are mainly concentrated on the quality of their Architectural and execution design submissions. Architectural students usually feel unsatisfied with their assessment grades during the project follow-up. This is mainly because they can't find or specify where are their problems or weak points and they cannot relate the staff theoretical comments into their projects upgrading. Experimental based teaching methods and the inspiring working environments have a great influence on the Architectural students psychology, which is reflected on the quality of their designs. Thus, this paper will explore the experimental based teaching approach as an innovative way that help in enhancing students performance and their design quality.
\end{abstract}

Keywords: Architectural education; experimental based study; working environment; creativity in architecture.

\section{INTRODUCTION}

Architectural education is a distinctive form of art studies enhanced by deep knowledge of how to design pleasant and livable spaces based on practical theories. Since that all human being are influenced by their built environment, it is very important to connect architects with their surrounding environment and society. The result will be a well-designed environment that has positive influence on the social behavior. There is no doubt that human behavior has a great influence in shaping the structure and form of the built environment. This mutual influence should be managed and directed by a well-educated architect who can clearly recognize the correct structures, proportions and colors. Academic institutions that seek to graduate a strong Architect in field, should design a curriculum that combines architectural theoretical education and experimental education and to connect them with the society needs and preferences (Salama A., 1995). Students Psychology is one of the major factors that could influence their working performance. By studying students behavior during many years and through different changes in place, systems, politics,...etc. working at pharos university (P.U.A) Architectural department for almost 10 years; the researcher has concluded some specific factors that have changed the students results either in good or bad way.

\section{INNOVATIVE TEACHING METHODS}

The main target of the architecture education is to teach students the better way to create meaningful three-dimensional structures that accommodate different human activities. Several studies have implied that the main problem facing the practice of architecture profession is the traditional educational system. This traditional method teaches the students without relating their knowledge with the society needs and their behavior. However, successful design that aims to find smart solutions for the community needs usually requires creative solutions (Rittel, H., et al., 1984). Enhancing students' creative skills will enable talented designers to find remarkable design solutions that can lead to a better environment. 
Unconventional problem perception can develop new concepts in the design ideas, which may orient students to innovative design solutions (Casakin, 2007). Students should learn that architecture is an important form of art that shape the build environment. Their real beauty comes when there is a good connection between the natural and the built environment in a successful functional design. Teaching strategies should focus on integrating both social responsibility and creativity in the design studies. It should also concern with creating an interactive working environment to enhance the educational psychological behavior of students (Salama A., 1995).

\subsection{Creativity in Architectural Education}

In the past, philosophy of creativity has been shown in the work of innovator, artist and musician. During this period creativity has been seen as a personal gift inspired form individual perceptual perception and own life experience (Salama A., 1995). According Immanuel Kant (1724-1804), this concept of creativity as a gift was called "romantic model" of creativity (Cowdroy \& Williams, 2006). The romantic model suggests that creativity is an innate force that cannot be promoted or fostered and it is usually the result of an artists (McIntyre, P., 2008). It was during the second half of the 20th century that Torrance had published a research that helped in changing the belief creativity as a gift to understand that it could be enhanced trough improving the creative behavior of human being (Torrance, 1963). With the architectural revolution in the $20^{\text {th }}$ century, creativity concept has changed to be promoted with human surrounding such as cultural, environmental and social influences. (Salama A., 1995). Steven Hurrt (2004) has made a comparison between both the 'geniusbased' and 'competence-based' learning strategies in relation to architecture studio pedagogy. He found that the 'genius-based' pedagogy is teacher-centered and is more useful for advanced academic level, whereas, the 'competence-based' pedagogy is learner-centered which focuses on the "body of knowledge" (Steven H., 2004). Creative architectural education emphasizes also the way of learning not just the information that should be learnt (Salama A., 1995). Thus, it becomes essential in architecture education to emphasis psychological aspects presented at the concept of creativity as behavior to enhance, both the teaching environment and the desired educational outcome (Plucker, 2002). However, there are many aspects (such as order, discipline, purpose, organization and directions) should guide creative behavior, as long as they are flexible to allow changes and innovation (Torrance, 1981 [1963]: 17). Casakin (2007) argued that creative problem solving should be the main target in the curriculum of first-year design studio to help novice architectural students in developing innovative concepts and ideas for the design solutions and to beat their lack of knowledge and experience (Casakin, 2007). The creativity in architecture design depend on personal discipline as well as strong self-perception of the surrounding environment and society needs. Since, the development of creative behavior depend on enlarging students knowledge, experience and readiness for ideas, architecture students should always be taken to live a new experience for a long or short period of time in order to enlarge the circle of their creative design thinking (Salama A., 1995; Cunliffe, 2008; Pederson \& Burton, 2009).

\subsection{Experimental based teaching methods}

It was Donald Schon (1984) who confirmed that the main and primary skill of the designer is the 'Reflexivity', which depends on the ability to reflect and learn from the real world experience rather than the 'Rationality', which depends on human mind problem solving. Badrinarayanan S. (2011) argued "objectivism" and "Constructivism "are the two major philosophies of knowledge. On one hand, Objectivism is based on transmitting knowledge from teachers (full vessels) to students (empty vessels). On the other hand, 
Constructivism is based on actively constructed knowledge, which is reflected from students' prior knowledge and experience. In this case, the role of teacher is to facilitate the construction of knowledge and guide it to be well translated into innovative design solutions. Thus, the Constructivism can be seen as 'dynamic' model of knowledge that swaps between the students' knowledge gained from their self-experience and the theoretical knowledge transferred from teachers to the students. This method permits the Staff member to be an "active teacher", rather than a 'full vessel' in transmitting their knowledge to the students (Badrinarayanan S., 2011).

Keeton and Tate (1978) defined the Experimental learning as: "when learners are in a direct contact with the reality being studied". This Experimental based teaching methods aim to engage students into real-life problem solving. They also expose students to different environmental circumstance and help them to enhance their perception of the architectural forms and spaces. In this way young students can enlarge their knowledge by storing information and data in their mind as inputs to be reflected later to generate more innovative designs. Some creative ideas for the experimental based teaching methods are explained as follows:

\section{a) Field trip}

Visiting the proposed site of the project and visualizing similar buildings are two forms of field trip that can be held before starting the conceptual design of any architectural project. Students are usually excited to explore new experiences during the field trip, as it help them in developing their perception of the architectural spaces as well as strengthen their sense of place. When people feel familiar with the spaces and the site, they turn psychologically relaxed, as there is no fear from the unknown. To realize the maximum benefit, students should submit a detailed report that record all collected information from the visit (Ashraf M. S., 2017).

\section{b) Architectural workshops}

Workshops are advanced trend used to supplement Architectural Design Studios. They mainly aim to develop students' skills and knowledge to enhance their creative thinking. This method has become recently an essential tool in active and creative architectural education (Katarína S., Alexandra D., 2016). According to Brooks-Harris argues, workshop can create an active and experiential learning environment, which aims to encourage participator to discover their innovative thinking (Brooks-Harris, J.E., 1999). Students tend to remember better things that are learnt under an experimental environment (Demirbas O.O., 2007). Workshops also enhance students' social behavior that helps them to accept others and communicate effectively. This communicative environment allows each student to share their ideas together and to gain self-confidence, which will have positive impact in their psychological behavior. Students will have also the opportunity to meet external people from different fields and disciplines. Furthermore, workshops involve students into real-live problem solving and prepare them for facing the architectural market (Katarína S., Alexandra D., 2016).

\section{c) International scientific programs and workshops}

International visits mainly aims to enrich the students' architectural knowledge through exposing them to several cultural and architectural styles. The experience gained from visiting different countries will have a direct influence on the students' creative thinking and behavior. By experiencing this kind of experimental study among a number of students who participated on the international workshops, it was found that they tend to be more creative and more understandable of their given projects assignments compared to their colleagues 
especially for beginners (second and third semesters). Also giving students the opportunity to visit many architecture schools that follow different approaches in architectural education, allow them and even their accompanied staff members to experience others education styles and may give inspiration for new ideas to enhance their performance in education or teaching.

\section{d) Summer Training}

Practicing architecture has becoming important and essential part of the architecture education worldwide. Experimental study that depend on real life experiences plays a vital role in enhancing students behavior as they can practice how to collaborate with their colleagues, managers and the public. Students are subjected to the architectural firm working environment whether in studios or in the site, which help them to enhance their physiological behavior, by feeling more responsible for their choices and having a collaborative spirit. Their perception of true and false could also be enhanced because of field observation in real life. Summer training is the most famous way that can give students the opportunity to practicing the architecture profession during their academic study. It helps in fostering the mutual understanding between class theoretical education and the real life work. In many architectural schools and universities, it is essential for undergraduate students to pass a number of hours in summer training distributes through three or four years in order to be graduated and certified to enter the architecture profession (Joseph A. D., 2001).

\subsection{Multidisciplinary and Social Responsibility in Architectural Education}

It is important to teach students that what differ an architect from a technician or an artist is his capability to design a creative and healthy built environment that meet the needs of community and society (Salama A., 1995). That is why many Universities have taken the community participation as a must in the education process through creating a community project in one of students' courses during the academic semesters.

\section{WORKING ENVIRONMENT}

Students learning architecture should begin their early stage of academic level by observing and learning from their surrounding environment. Architectural students have different way for study and work, their working time could not be resumed in some working hours in class and home, their work continues during their 24 hours of living day. Their master goal is the Design project. It starts in the Design studio and continues through the rest of the day and weeks till the project submission time.

Providing favorable and appropriate learning and working environment is also essential to foster students' creative behavior and to be translated into the final product of their designs (Cropley, 1997).

\subsection{Working Studios}

Architectural studios are the places where a young architect is molded. Those studios represent the core of the architectural education. Students have usually a strong attachment to the place of their daily work (Salama A., 1995). According to Giuliani, M. V. and Feldman, R. (1993), place attachment is defined as a psychological condition of human being resulting from a frequent accessibility to a place (Giuliani, M. V. and Feldman, R., 1993). There are also some scholars who argued that long-term interaction with place and memorable activities 
could create strong attachment to the place (Mina N. and Mustafa Kamal B. S.; 2011). Moreover, the level of people's place satisfaction; can be seen as significant reason that have a great role in the formation of place attachment. Stedman defines that the overall satisfaction within the place is influenced by place elements (Steadman, C. R., 2003). The satisfaction of place element is influenced by user preferences and perception of the space (Mina N. and Mustafa Kamal B. S.; 2011). Steadman supposed that the physical environment, its elements and characteristics could lead to the construction of sense of place. He also argued that the enhancing physical characteristics of a space can strengthen the feeling of place attachment and risen the level of satisfaction (Steadman, C. R., 2003). The sense of place can be defined as people's subjective perception of their surrounding environment. Thus, Sense of place is both expository and emotional aspects related to human psychological and their perception of physical elements (Mina N. and Mustafa Kamal B. S.; 2011).

For the Architectural work environment, Open studios can encourage students for interactive learning, creative thinking and a strong assimilation (Salama A., 1995). Students use their studios for design project and learning construction details almost 16 hours per week, so the place should be well designed with creative idea to be as inspirational place and also to be comfortable for these very long working hours. Their interior style can be inspired from different architectural schools to mimic development and transformation of styles over time such as simplicity, deconstruction, modernism etc. Each studio of different academic level can have its own characteristics. This change will help students to learn about the most distinctive architectural styles to recognize the difference between them.

\subsection{Computer Lab}

Providing architecture school with all needed facilities such as computer labs equipped with advanced programs (3Dmax, AutoCAD, Rhino, Grasshopper, etc.) will make students feel more comfortable and attached to their working place and give them the space to apply new and creative design. Also providing workshops spaces equipped with all machines they might need such as laser cutter machine, 3D printer, plotter, etc. and many others equipment give them more time to work better and present their ideas with different tools freely without feeling stuck on time and place. Architecture Representation and Computation strategy is currently undertaken by many universities around the world as an advanced education methodology in responding to digital revolution and its relation in enhancing the architectural creativity. It has been also researches in that area in many universities such as the research taken at the MIT University in the USA, which aims to prove that the innovative use of advanced computer programs (software and hardware) can provide creativity in problem solving in the contexts of architectural design practice. (https://architecture.mit.edu/program/labs-and-research)

\subsection{Environmental Lab}

Connection between the built and natural environment in the architectural education has become recently the subject of more studies due to the increasing attention of the harmful impact that can be caused by the building construction both on human health and the ecosystem. The aim of this environmental approach in architectural education is to help students in recognizing and assessing benefits and dangers of building alternative designs on their environmental contexts. With this evaluation students are trained to find the optimum level of satisfaction in designing a building that benefit from the natural aspect presented in its context as well as minimizing its harmful impact both of the ecosystem and human wellbeing. Visual aesthetic and comfort, Climatic comfort and clean environment are all essential 
preconditions a good architecture quality. The success of an architect in designing the built environment depends on the building efficiency that can ensure the achievement of that the previous aspects. For this reason, environmental labs become very important in the architectural education to help students and researcher to related the building design with the climatic performance in order to achieve maximum efficiency. A well-equipped environmental lab is equipped with instruments and software is important to provide climatic data monitoring for building both in the design stage and in the Post occupancy evaluation studies. These may include but not limited to the following instruments (see table 1). The lab could also be equipped with live scale demonstrative models of several passive or active environmental features such as lighting with Solar panels, passive cooling technologies like radiant cooling, structure cooling and evaporative cooling systems, etc.

Table 1: Some of environmental lab instruments. Source: https://www.bnca.ac.in/academics/masters-ofenvironment-architecture/environmental-lab-reed/

\begin{tabular}{|l|l|}
\hline \multicolumn{1}{|c|}{ Name of Instrument } & \multicolumn{1}{c|}{ Purpose of Use } \\
\hline Lux Meter & To measure illumination levels indoor \\
\hline in 1 Environmental Meter & $\begin{array}{l}\text { Measures all 5 parameters (illumination, sound, humidity, temperature and } \\
\text { airspeed) }\end{array}$ \\
\hline Anenometer & Measures air speed \\
\hline Sound meter & Measures decible levels outdoor and indoor \\
\hline Data Logger (Wireless or not) & Measures temperature and humidity in a closed space. \\
\hline Thermohygrometer & Records temperature and humidity \\
\hline Infrared Thermometer & Measures surface temperature of materials \\
\hline Thermal Imager & Measures thermal range of building surfaces through photographic sensors \\
\hline $\begin{array}{l}\text { Humidity and Temperature } \\
\text { Data Logger }\end{array}$ & $\begin{array}{l}\text { Measures continuous temperature and humidity together in a space and data can } \\
\text { be transferred to desktop }\end{array}$ \\
\hline CO2 sensors & Measures indoor air quality for its CO2 emissions \\
\hline Heliodome & $\begin{array}{l}\text { It is a device that simulates the angle at which sunbeams strike a physical model } \\
\text { of a building. It allows easy understanding of solar geometry and its impact on } \\
\text { buildings }\end{array}$ \\
\hline
\end{tabular}

\section{Case Study: Assessing the Impact of Experimental Learning on Architecture Student's Performance at the PUA.}

Pharos University in Alexandria (PUA) is a private university that was established in 2006 and became a leader on the architectural education study. It has introduced many of the experimental based teaching methods as an essential part of the architectural design and execution design courses. Since, 2010 till today there have been strategies to organize and ensure the use of these methods. Students have feeding their knowledge through several field trips, architectural workshops, international educational visits and summer training (see table 2). It was obvious that students participating in such activities have enhanced their creative behavior.

Table 2: Presents the experimental teaching methods used at different architectural levels in PUA

\begin{tabular}{|l|l|l|}
\hline Method & Timing & Outcomes \\
\hline
\end{tabular}




\begin{tabular}{|c|c|c|c|}
\hline 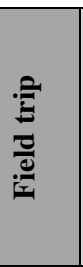 & $\begin{array}{l}\text { There is a schedule with all } \\
\text { site visits in architectural } \\
\text { and execution design } \\
\text { courses specified } \\
\text { according to the selected } \\
\text { project. There should be } 2 \\
\text { site visits during each } \\
\text { semester for each course. }\end{array}$ & $\begin{array}{l}\text { Each semester from fall 2010- } \\
2011 \text { till today (Fall 2019-2020). }\end{array}$ & $\begin{array}{l}\text { Enhancing students perception of architectural spaces, } \\
\text { structures and materials. It was obvious that after returning } \\
\text { from site visit, students can find appropriate solutions by their } \\
\text { own to many problems that they face in their projects. }\end{array}$ \\
\hline \multirow{5}{*}{ 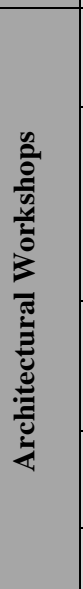 } & $\begin{array}{ll}\begin{array}{l}\text { Parametric design } \\
\text { workshop }\end{array} & \end{array}$ & 2 weeks from 2-14 February 2015 & $\begin{array}{l}\text { It develops students' skill to create their Work models. The } \\
\text { visible outcome was a flexible Pavilion: using computer } \\
\text { programs (Rhino, Grasshopper) }\end{array}$ \\
\hline & $\begin{array}{l}\text { Designing new } \\
\text { Architectural studios walls }\end{array}$ & 2 months July - August 2015 & $\begin{array}{l}\text { It develops students' skills in designing and seeing their } \\
\text { design applied in the real life. The visible outcome was the } \\
\text { existing wall design of the four studios at Pharos University. It } \\
\text { was noticed that students participated at the international } \\
\text { scientific program and workshops have developed creative } \\
\text { ideas, which was influenced by their experiences abroad. }\end{array}$ \\
\hline & $\begin{array}{l}\text { Computer tools for } \\
\text { architectural drawings } \\
\text { presentations(Advanced } \\
\text { Auto-Cad, 3d max) }\end{array}$ & $\begin{array}{l}1 \text { month July } 2018 \\
\& \\
1 \text { month July } 2019\end{array}$ & $\begin{array}{l}\text { It develops students' skills in using architectural computer } \\
\text { programs. }\end{array}$ \\
\hline & $\begin{array}{ll}\text { Manual } & \text { presentation } \\
\text { techniques. }\end{array}$ & 1 month July 2019 & $\begin{array}{l}\text { It develops students manual presentation skills. It was } \\
\text { reflected in phase or final submission of their projects in the } \\
\text { design courses especially for } 2^{\text {nd }} \text { and } 3^{\text {rd }} \text { semesters. }\end{array}$ \\
\hline & $\begin{array}{ll}\text { Rehabilitation } & \text { of } \\
\text { Architectural models }\end{array}$ & 1 month July 2019 & It develops students' skill to create their Work models. \\
\hline \multirow{5}{*}{ 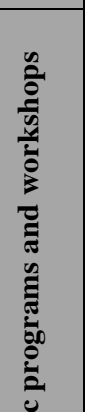 } & Dubai, UAE & One week, Fall 2011-2012 & \multirow{9}{*}{$\begin{array}{l}\text { It has been } 9 \text { nears that the Department of architecture at } \\
\text { pharos university in Alexandria is keen to continue the } \\
\text { strategy of international workshops every year. Each year } 25 \\
\text { students can have the opportunity to participate at the } \\
\text { scientific program. These visits aim to wider the scope of } \\
\text { students' knowledge and to feed their memories with } \\
\text { information that they couldn't have the opportunity to see in } \\
\text { their hometown. The workshop takes place at one of the } \\
\text { recognized university or schools of architecture in the several } \\
\text { visited countries. Students are introduced to the ways of } \\
\text { studies at the different universities and then they explore } \\
\text { significant buildings at the cities accompanied with staff } \\
\text { members. It was obvious that students participating at this } \\
\text { kind of international workshops, have became more flexible in } \\
\text { design thinking and creativity as they have been exposed to } \\
\text { different architectural styles and cultures. This kind of } \\
\text { international workshop has a positive impact for overal } \\
\text { architecture department students at PUA because when } \\
\text { students return form the visit, they transfer their experiences to } \\
\text { their colleagues weather during the studio or by presenting a } \\
\text { Video that resume all their achievement during the visit. }\end{array}$} \\
\hline & Rome, Italy & One week, Spring 2012-2013 & \\
\hline & $\begin{array}{l}\text { Paris, France } \\
\text { ( Belleville-Ecole nationale } \\
\text { superieure d'architecture) }\end{array}$ & One week, Spring 2013-2014 & \\
\hline & $\begin{array}{l}\text { Berlin, Germany } \\
\text { (Technische Universitat } \\
\text { Berlin) }\end{array}$ & One week, Spring 2014-2015 & \\
\hline & $\begin{array}{l}\text { Vienna, Austria } \\
\text { (Technshe Universitat } \\
\text { Wien) }\end{array}$ & One week, Spring 2015-2016 & \\
\hline 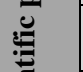 & $\begin{array}{l}\text { New Delhi, Japura, India } \\
\text { (Jamia Millia Islamia) }\end{array}$ & One week, Fall 2016-2017 & \\
\hline \multirow{3}{*}{ 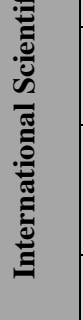 } & $\begin{array}{l}\text { Moscow, Russia } \\
\text { (Moscow State University } \\
\text { of Civil Engineering) }\end{array}$ & One week, Spring 2016-2017 & \\
\hline & $\begin{array}{l}\text { Barcelona, Spain } \\
\text { (Universitat Politecnica de } \\
\text { Catalunya- Barcelona } \\
\text { Tech) }\end{array}$ & One week, Spring 2017-2018 & \\
\hline & $\begin{array}{l}\text { New Delhi, Japura, India } \\
\text { (Jamia Millia Islamia) }\end{array}$ & ek, Spring 2018-2019 & \\
\hline \multirow{2}{*}{ 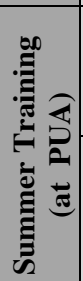 } & $\begin{array}{l}\text { Designing the permanent } \\
\text { corridor Exhibition }\left(5^{\text {th }}\right. \\
\text { floor })\end{array}$ & 2 months July - August 2015 & $\begin{array}{l}\text { The visible outcome was the existing permanent exhibition of } \\
\text { the corridor (presenting students works) at Pharos University. }\end{array}$ \\
\hline & $\begin{array}{l}\text { Designing new extension } \\
\text { of the permanent corridor } \\
\text { Exhibition }\left(4^{\text {th }} \& 6^{\text {th }} \text { floors }\right)\end{array}$ & 1 month July 2019 & $\begin{array}{l}\text { It develops students' skills on the space perception and } \\
\text { enhances the teamwork skills. }\end{array}$ \\
\hline \multirow{2}{*}{ 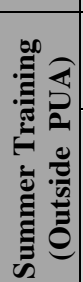 } & $\begin{array}{l}\text { On site (construction or } \\
\text { finishes) }\end{array}$ & $\begin{array}{l}\text { Every year during summer (from } \\
3 \text { to } 4 \text { weeks) }\end{array}$ & $\begin{array}{l}\text { Students gain experiences on construction process, which has } \\
\text { a positive impact on the quality of their submission in the } \\
\text { execution design courses. }\end{array}$ \\
\hline & $\begin{array}{l}\text { Architectural consultant } \\
\text { offices or firms }\end{array}$ & $\begin{array}{l}\text { Every year during summer (from } \\
3 \text { to } 4 \text { weeks) }\end{array}$ & $\begin{array}{l}\text { Students gain experiences on designing process and their } \\
\text { presentation using computer tools, which have a positive } \\
\text { impact on the quality and creativity of their submission in the } \\
\text { Architectural design courses. It also develops the teamwork } \\
\text { skills between students. }\end{array}$ \\
\hline
\end{tabular}

\subsection{Field Trip strategy and its impact on architectural students at PUA}

Students of the $6^{\text {th }}$ semester taking the Architecture Design course level 4 (fall 2019-2020) were the targets of the study. The students were asked to design a "medical center" in a selected land in Roushdy, Alexandria. During the preliminary design concepts, staff members 
have noticed common problems and mistakes on the following: the recognition of the clinics spaces and proportions; relation between nursing station and waiting area with the clinics zones, also the design of the ICU zone.

To help students in understanding all these circulation relationship correctly; a site visit to the outpatient area in "Alexandria new medical center" in Smouha was arranged (third week form the beginning of the project) for all students and staff. During the tour, the group was accompanied with a doctor and an architect to explain on site circulation of doctors and patients and all procedures needed for each use. The relationship between clinics, nurse station and waiting area was also explained. Then, the students went to the ICU to recognize it spaces clearly.

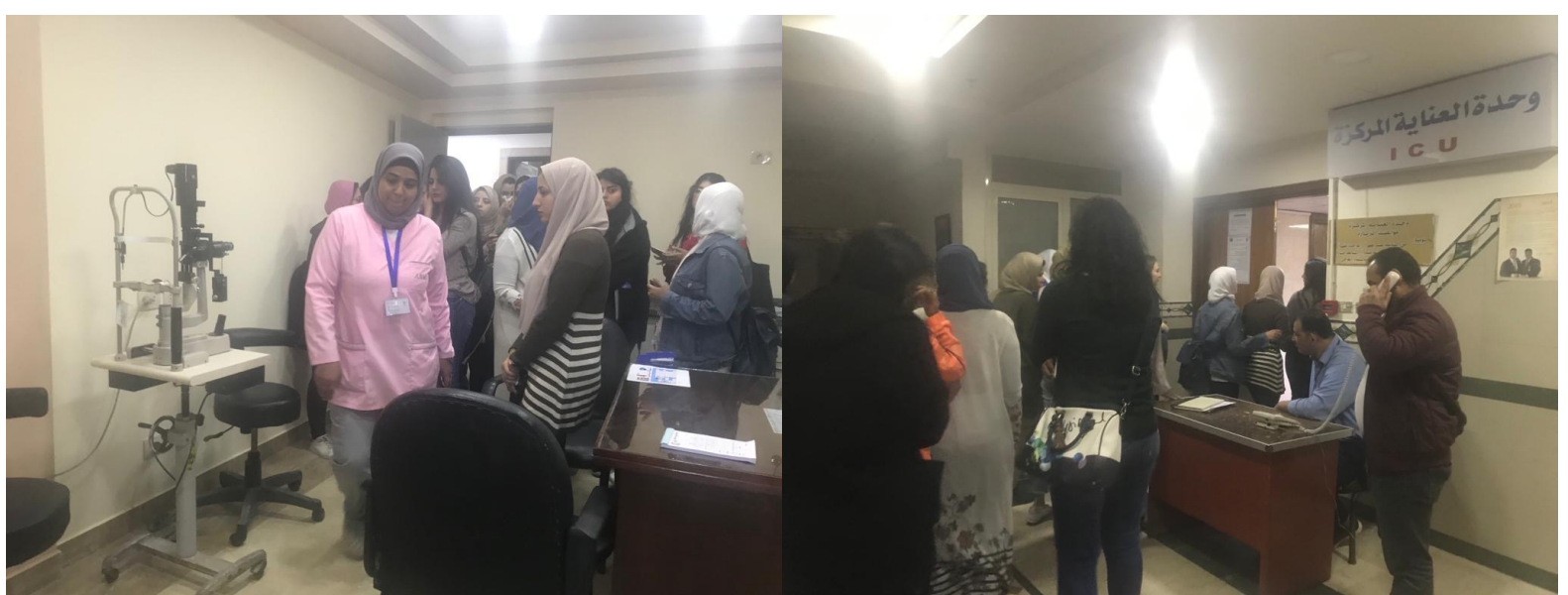

Figure 1: To the left, students visiting the optical clinic; to the right, students visiting the ICU at the "Alexandria new medical center". Source: Photo taken by the Author.

After this visit, students were asked to re-evaluate their design proposals by themselves; each student took his own design and his notes from the visit and started to correct all circulation mistakes. By re-assessing those designs from the staff members and comparing with the old ones, a remarkable progress was found. Students were able to have a clear vision and understanding of all zones relationships after visiting the clinical and ICU zone in "Alexandria new medical center".

\subsection{Designing survey Questionnaire}

A questionnaire was made to survey the effect of using one of the experimental based teaching methods on enhancing students performance and creative behavior. The survey questionnaire aimed to verify the impact of the site visit related to the given architecture project (within the Architecture design course) on students design outputs. The researcher formulated two questionnaires one submitted to the 47 students of design 4 (fall 2019-2020) and the other one for the 6 staff members who are enrolled in the course.

Questionnaire for students:

i. Did you benefit from the visit to Alexandria medical center?
a) Yes
b) No
Comments

ii. What are the problems that you faced during the design process?
a) Structure
b) Space proportions
c) Zones relationship
d) Design of IUC
d) Parking

Note: (You can choose more than one)

iii. Did the site visit give answers for these problems? 

a) Yes
b) No
c) Not all of them

iv. Was the visit in the right time of your design process or should it be earlier?
a) Yes
b) No
Comments:

Questionnaire for staff members:

i. Did you notice an improvement in the quality of design proposal submission?
a) Yes
b) No
Comments:

ii. During which week of the project do you prefer to make it?

iii. What are the criteria in choosing the site visit (doctors only)?

\subsection{Results and Discussions:}

A percentage of $79 \%$ form the total students enrolled in the course agreed that they had benefit form the site visit. They argued that some times staff theoretical comments are not clear enough for them and that this type of experimental study is very useful as it brought them into a direct contact with the medical center spaces on the real world. While the $21 \%$ of students find that they have previously experienced going to such spaces and they were already aware about those data. Students answered the question of problems facing their design according to the following percentages: $17 \%$ structure, $21 \%$ Space proportions, $42 \%$ Zones relationship, 53\% Design of IUC, and 25\% Parking. The majority of $58 \%$ of students agreed that the site visit has helped them in finding solutions for their design problems. While $21 \%$ of students said No and some of them give comments such as: "we struggle to implements design theories in our design"; "the site visit didn't add to our knowledge because we already experienced such spaces and we prefer comments on our projects". And the rest $21 \%$ said that the site visit gives answers for some of their problems not all of them. A majority of $75 \%$ of students agreed that it was the wright time for the visit because it comes right after discovering their problems and it will help them to overcome these obstacles during the next submissions. While the $25 \%$ didn't agree that it is the right time, as some of them preferred to have it in the first week of project and others preferred not to have it at all. For the staff questionnaire, $100 \%$ of doctors and teaching assistants agreed that they noticed an obvious improvement in the quality of students' submissions with a percentage of $70 \%$ of all students. They tend to understand better the theoretical spaces relationships and proportions. However, they may have some problems related to drawings presentations. All staff agreed that the site visit is better to be during the second or third week of the project, it depends sometimes upon the available time at the site that they want to go. They believe that students should try to design first to identify their problems and then trying to discover the solutions by their own. In this way, they will not forget the experience and will have some add to their knowledge not just following the staff instructions. Doctors answered that the criteria of choosing the location of the site visit depend on the type of the project and the availability of a reachable similar project. It is also beneficial to visit the location of the given site itself to analyze the urban context of the project. Sometimes, when the site is not easy accessible for all students, the field trip may be organized to the selected site.

\section{Conclusion}

The questionnaire has some limitation as it test only one methods of the experimental study on one semester of architecture students and perhaps needed to be distributed across all semesters to test the effect of different experimental methods on average students design 
competence. However, the research results have highlighted the efficiency of using experimental teaching method over the conventional teaching method in improving students design performance. The example of the continuous adoption of the four experimental teaching methods in studying Architecture at Pharos University in Alexandria (PUA) may encourage other Universities in shifting the paradigm of architecture education into experimental environment. The field trip is considered the easiest and cheapest form of experimental methods, as it does not require additional time or money. Thus, it is recommended to add this experimental method into the curriculum of the Architectural and Execution design courses to unsure its continuity even with leadership changes.

\section{REFERENCES}

1. Salama A. (1995). "New trends in Architectural Education: Designing the design Studio". Tailored text and unlimited potential publisher, North Calorina, USA.

2. Rittel, H. W. J., \& Webber, M. M. (1984). Planning problems are wicked problems. In N. Cross (Ed.), Developments in design methodology (pp. 135-144). New York: John Wiley \& Sons.

3. Casakin, H. (2007). Metaphors in design problem solving: implications for creativity. International Journal of Design, 1(2), 21-33.

4. Cowdroy, R., \& Williams, A. (2006). Assessing creativity in the creative arts. Art, Design \& Communication in Higher Education, 5(2), 97-117.

5. McIntyre, P. (2008). Creativity and cultural production: a study of contemporary western popular music songwriting. Creativity Research Journal, 20(1), 40-52.

6. Torrance, E. P. (1963). Toward the more humane education of gifted children. Gifted child Quarterly. 7.135-145.

7. Giuliani, M. V., \& Feldman, R. (1993). Place attachment in a developmental and cultural context. Journal of Environmental Psychology, 13, 267-274.

8. Plucker, J. A. (2002). What's in a name? Young adolescents' implicit conceptions of invention. Science Education, 86(2), 149-160.

9. Mina N., Mustafa Kamal B. S. (2011). The Concept of Place and Sense of Place In Architectural Studies. International Journal of Human and Social Sciences 6:3

10. Steadman, C. R. (2003). Is it really just a social construction: The contribution of the physical environment to sense of place. Society and Natural Resources, 16, 671-685.

11. Katarína S., Alexandra D. (2016). Workshop as a tool in architectural education. World Transactions on Engineering and Technology Education. WIETE. Vol.14, No.1

12. Brooks-Harris, J.E. and Stock-Ward, S.R. (1999). Workshops: Designing and Facilitating Experiential Learning. UnitedStates of America, SAGE Publications Lt.D.

13. Demirbas, O.O. and Demirkan, H. (2007). Learning styles of design students and the relationship of academicperformance and gender in design education. Learning and Instruction, 17, 345-359.

14. Ashraf M. S. (2017). Appropriate teaching and learning strategies for the architectural design process in pedagogic design studios. Frontiers of Architectural Research. Elsevier. Vol. 6. 204-217

15. Joseph A. D. (2001). The Architect's Handbook of Professional Practice. The American Institute of Architects. John Wiley \& Sons.USA.

16. Steven W. H. (2004). 'Characteristics of Studio Education in Architecture: A Primer for the Uninitiated, a Critique for the Informed' in Stephanie E. Bothwell, et al, editors, Windsor Forum on Design Education, Towards an Ideal Curriculum to Reform Architectural Education. Miami, Florida: New Urban Press, p. 267. 
17. Badrinarayanan S. (2011). Application of Kolb's Experiential Learning Theory to Teaching Architectural Design Principles. Design Principles And Practices: An International Journal. Vol.5. Common Ground Publishing. Illinois, USA. ISSN 1833-1874

18. Bhanuben N. Environmental Lab - REED. Retrieved 29 November 2019. Available at: https://www.bnca.ac.in/academics/masters-of-environment-architecture/environmentallab-reed/

19. Takehiko N. Massachusetts Institute of Technology School of Architecture + Planning. Retrieved 29 November 2019. Available at: https://architecture.mit.edu/faculty/takehikonagakura 